\title{
MARKET ANALYSIS OF FINANCIAL INSTITUTIONS AND ENTREPRENEURSHIP IN INDIA
}

\author{
Dr. Sheeza Ismail Patel \\ The University of Wollongong, Australia
}

\begin{abstract}
:
The purpose of this research is to investigate early-s.tage ease/difficulties faced by Start-Ups /MSME in India. The research is based in Bengaluru, Karnataka, India, five major banks located in the city were approached. The amount of support offered by banks to open a business bank account was investigated through interaction with representatives. It was found that banks offered several services at low charges and minimum requirements to ease the burden on new businesses. However, financial institutions do not offer early-stage funding, this made the new businesses struggle to gain initial working capital.
\end{abstract}

Keywords: Entrepreneurship, financial institutions, Innovation, MSME, Start-Ups.

Cite this Article: Dr. Sheeza Ismail Patel, Market Analysis of Financial Institutions and Entrepreneurship in India, International Journal of Management, 10 (6), 2019, pp. $1-7$.

http://iaeme.com/Home/issue/IJM?Volume $=10 \&$ Issue $=6$

\section{INTRODUCTION}

The standard practice of business studies towards entrepreneurship is opportunity identification and new venture creation. Global Entrepreneurship Monitor (GEM) defines an 'entrepreneur' as an adult who is engaged in setting up or operating a new venture that is less than 42 months old (Parker, S. C. 2018). Entrepreneur catalyzes the process of economic development. The concept of equating new venture creation with entrepreneurship fails in several ways as most of them are 'replicative' rather than 'innovative' in nature. Innovative entrepreneurs create new products and processes that boost economic growth, while replicative entrepreneurs answer to the demand of a growing population by replicating a successful idea. Nevertheless, both contribute to economic growth, while innovative ventures are the cause of economic boost, replicative ventures are symptoms of growth.

Entrepreneurship in India was earlier limited to the family business that created an ecosystem that incubated new generation to learn hands-on traditional business models with little innovation- funded by cash cows of the business and angel investors (Forbes India, 2019). With the emergence of technological innovation, the new generation of start-ups challenges the traditional business models. The professional network forms the main ecosystem of these 
ventures. The purpose of this paper is to investigate the amount of support received by financial institutions for the innovators to embrace entrepreneurship.

\section{LITERATURE REVIEW}

A popular definition of an entrepreneur in business studies is someone who perceives an opportunity and creates an organization to pursue it (Bygrave and Hofer, 1991) often without the resources to do so. The creation of a new venture is the essence of entrepreneurship (Parker, S. C. 2018). From economists, perspective entrepreneurs are defined as self-employed individuals or small business owners. That being said, not every business owner can be an entrepreneur there are certain qualities to be taken into consideration (Drucker, 1985). An entrepreneur needs to have a growth mindset, be an action-oriented, highly motivated individual, with the ability to create, dedicate and discipline themselves towards their goals not to forget readiness to take risks, flexibility to change and innovate.

A historical overview of entrepreneurship did not consider entrepreneurs as contributing to the economy and society at large. Today, however, entrepreneurs are held responsible for economic development, by introducing and implementing innovative ideas.

These ideas include product innovation, process innovation, market innovation, and organizational innovations. The successful implementation, initiated by entrepreneurs, of these new ideas, gives rise to the satisfaction of new consumer wants and the creation of firms. The created firms engender economic growth and supply jobs for the working population. Hence, by stimulating both a product market and a labor market, entrepreneurs can be given credit for a considerable contribution to the economy. These are the benefits of successful entrepreneurship (Van Praag, C. M. 1999), not all entrepreneurs are successful, and many fail due to financial, psychological and social costs.

To summarize, an entrepreneur is a person who takes, innovative solutions to a problem and turns them into financially viable opportunities while accepting uncertainty and risks associated with it, to create demand, wealth and employment

\section{TERMINOLOGIES}

Proprietorship: "It simply refers to a person who owns the business and is personally responsible for its debts." (Entrepreneur, 2019)

Partnership: "A legal form of business operation between two or more individuals who share management and profits. The two most common are general and limited partnerships." ("Sole Proprietorship Definition - Entrepreneur Small Business Encyclopedia", 2019)

LLC: "LLC is a legal form of a company that provides limited liability to its owners in many jurisdictions. LLCs are well known for the flexibility that they provide to business owners; depending on the situation, an LLC may elect to use corporate tax rules instead of being treated as a partnership, and, under certain circumstances, LLCs may be organized as a not-forprofit" ("Sole Proprietorship Definition - Entrepreneur Small Business Encyclopedia", 2019).

Corporation: "A corporation is a legal entity that is separate and distinct from its owners. Corporations enjoy most of the rights and responsibilities that individuals possess: they can enter contracts, loan and borrow money, sue and be sued, hire employees, own assets and pay taxes" ("What Everyone Should Know about Corporations", 2019).

PAN card: PAN, or permanent account number, is a unique 10-digit alphanumeric identity allotted to each taxpayer by the Income Tax Department under the supervision of the Central Board of Direct Taxes (business today, 2019). 
GST/CST certificate: Goods and services tax registration certificate, from the concerned tax authorities to collect tax on behalf of the government and to avail Input Tax Credit. CST is Central sales tax certificate, for indirect tax on goods sold from one state to another.

CIBIL (Credit Information Bureau (India) limited): is a Credit Bureau or Credit Information Company that maintains all the credit-related activities of a company. The registered financial institutions periodically submit information to CIBIL based on which it issues credit score.

\section{OBJECTIVES OF THE STUDY}

The objective of this study is to investigate the following:

1. Requirements for start-ups/MSMEs to open a bank account.

2. Minimum balance required for opening a business bank account.

3. Minimum monthly balance required to maintain the business bank account.

4. Monthly service charges.

5. Length of time to open a business bank account.

6. Minimum required turnover of the business.

7. Level of financial support provided to new business.

\section{METHODOLOGY}

The study was conducted in Bengaluru, State of Karnataka, India. Bengaluru is the start-up hub of India which homes 5 out of 8 Unicorns of India and receives the fifth-largest amount of funding. The research, however, will focus on gathering information from financial institutions such as banks. A similar study was conducted to research the amount of support offered by banks located at the county of San Diego, California.

This paper is modified to evaluate the start-up ecosystem of India. Five major banks were chosen as a model for this study: The State Bank of India, Bank of Baroda, Axis Bank, ICICI Bank, and HDFC Bank. Bank representatives were asked the following questions: Requirements for start-ups to open a bank account, Minimum balance required for opening a business bank account, Minimum monthly balance required to maintain the business bank account, monthly service fees, Length of time to open a business bank account, Minimum required turnover of the business to avail loan, Level of financial support provided to new business.

\section{ANALYSIS}

\subsection{The requirement to open a bank account}

The basic requirements for opening a business bank account in all five banks were similar. The required documents included- Proof of identity - PAN card, voter ID card, passport, driving license, proof of address, Recent Colour Photograph, PAN/Form 49 A along with Form 60 if applied for PAN (for individuals without PAN), Account opening Cheque from existing Savings/Individual Current Account.

In addition, requirements for proprietorship include, Certificate from a State Government or Statutory Body/Trade License/Sales Tax Certificate/Shop and Establishment Certificate, Letter of proprietorship duly signed by the proprietor, GST/CST certificate, IEC (Importer/Exporter Code by the Office of Director General of Foreign Trade (DGFT) in the name of Proprietary Concerned.

For Partnership firms, the additional requirements include PAN of partnership firm, Partnership Deed and Registration Certificate, Establishment Certificate, a letter from partners authorizing opening and operating the account. 


\subsection{Minimum balance required for opening a business bank account.}

The minimum balance required by banks ranged from 'Pay as you use' to INR. 25000. Most banks required a minimum balance of INR 10,000, however, some banks offered NIL initial balance with maintaining a quarterly average of INR 2,500. The intention behind is to kickstart businesses and avail services hassle-free.

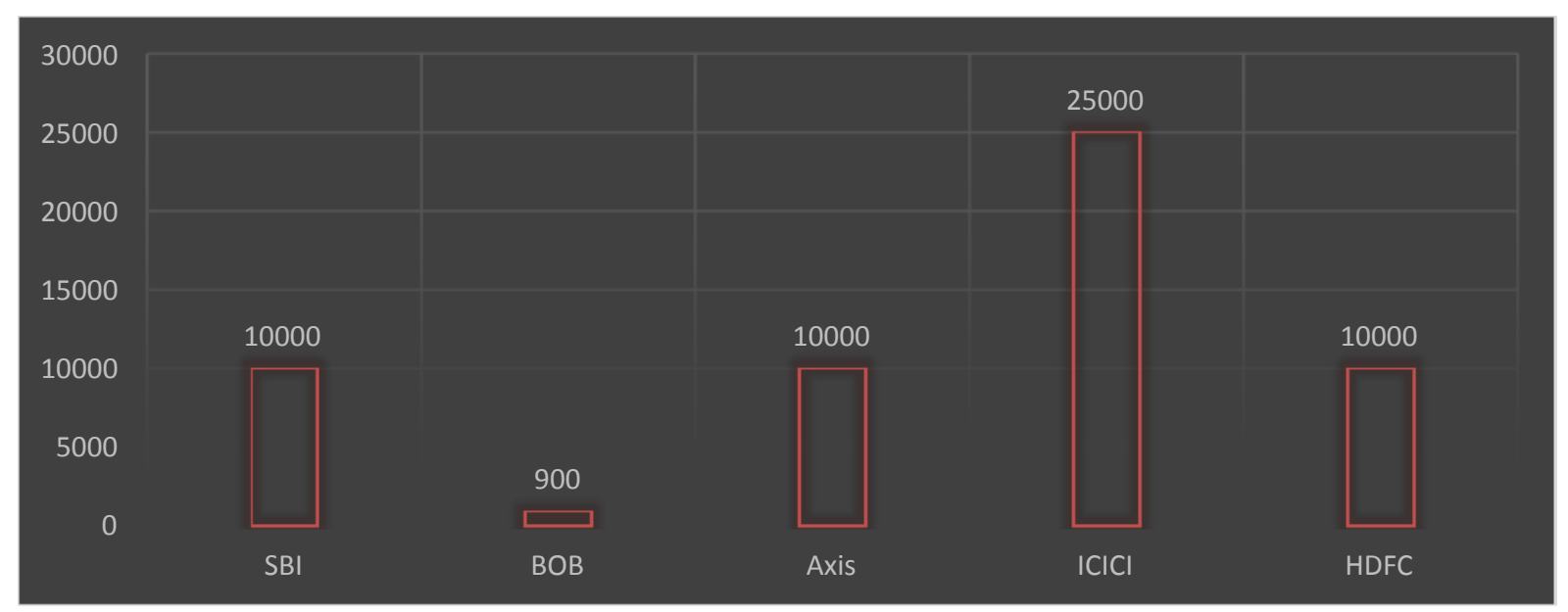

\subsection{Minimum monthly balance required in the business bank account.}

The minimum monthly balance required ranges from zero to 25,000 INR. Banks offer several options to the businesses based on their stage, from inception to establishment. The monthly minimum balance account for New Start-up current account is Nil, while in some cases it can be Nil for the first six months thereafter it is INR 25,000. The average monthly minimum balance required by most banks is INR 10,000, while it is quarterly INR 10,000 in other banks. Start-Ups have the facility to choose the account type according to their business needs in the same bank.

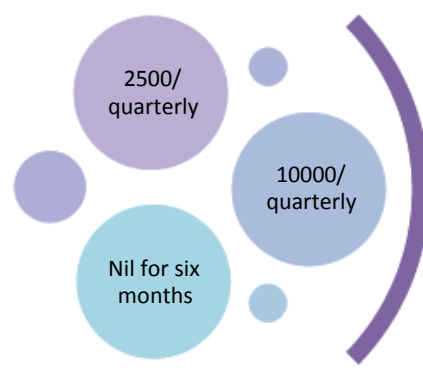

New Start-Up Current Account

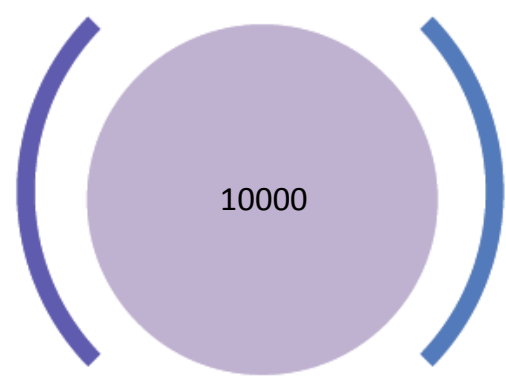

Monthly average Balance for most bank accounts

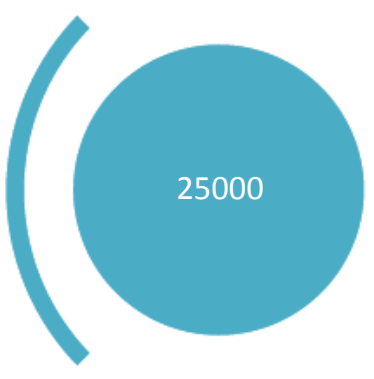

Business Advantage Current Account

\subsection{Monthly Service fees}

Indian Banks charges vary for different services, including initial waive-offs like, free digital transactions, debit cards are generally waived off service fee for the first year thereafter they are charged, Depositing cash beyond 50,000 INR is charged while for some banks it is 25,000 INR, with unlimited withdrawal, cheques are charged after 50 issued, statement of the account is issued twice free of charge.

Most banks charge accounts for non-maintenance of minimum balance. It can from INR 350 per quarter to INR 5000. While some banks charge straight up 50 INR per month. 


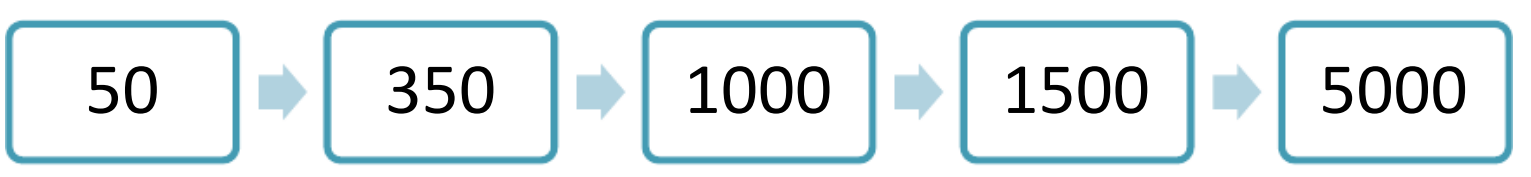

\subsection{Length of time to open a business bank account.}

The time required to open the bank account depends on the availability of all the required documents. The services are pretty quick if all documents are precise. It may take 15 minutes to 45 minutes to register for the account. The activation may take place on the same day or a week.

$1545 \quad 4$ to 5 days

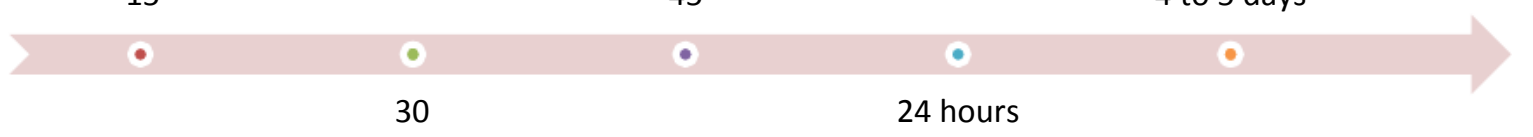

\subsection{Minimum required turnover of the business}

There is no minimum turnover required by a business to open a business bank account with any of the analyzed banks. Entrepreneurs can approach the bank to sanction them business loans. The banks take into account the turnover rate for companies existing for 36 months, the range of turnover required is from $20,00,000$ INR to $1,00,00,000$ INR.

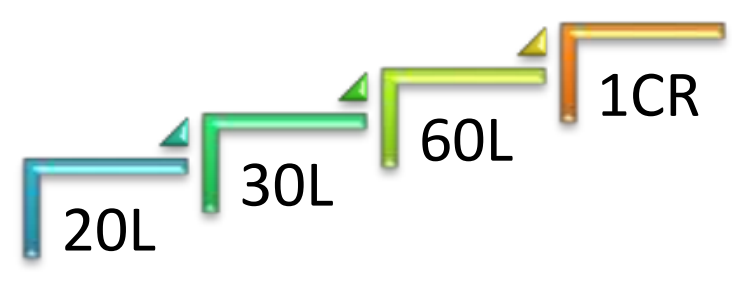

\subsection{Level of financial support provided to new business}

Indian banks provide financial support to entrepreneurs through various government schemes and working capital loans. Government schemes such as Pradhan mantra mudra yojana, StandUp India offers loans to the homegrown enterprise from 50,000 rupees to 10 lakh based on the stage of growth/development and funding needs. Banks offer technology-based start-ups working capital financing through cash credits, overdraft or working capital loans according to their risk profile.

Based on CIBIL score (300 - 900), age of business (36 months), turnover rate and age of the entrepreneur (21 - 65 years) loans are offered from 1,00,000 to 50,00,000 INR on an average interest rate of $15 \%$.

\section{CONCLUSION}

Indian start-up ecosystem hosts nearly 40,000 start-ups, producing unicorns and high profile exits with international players. The micro, small and medium enterprise sector values 577CR. Despite the development, many ideas fail to take a flight due to a lack of working capital. An established start-up attracts investors, however, getting funding for an early-stage idea is a tremendous challenge.

The initial stages of starting a business include setting up a business bank account. The goal of this research paper is to investigate the amount of administrative and financial support given to the start-ups by financial institutions of India. The study revolves around the following questions- Requirements for start-ups to open a bank account, Minimum balance required for 
opening a business bank account, Minimum monthly balance required to maintain the business bank account, monthly service fees, Length of time to open a business bank account, Minimum required turnover of the business to avail loan, Level of financial support provided to new business.

The documentation procedure for opening a business bank account is simple yet a lot of documents are required to register an account for proprietorship. The banks offer 'pay as you use' services to ease the burden on businesses, while others offer very low minimum balance required to open an account. The banks offer entrepreneurs various business account types such as- New start-up current account, Shubh Arambh (new beginning), business advantage current account, which include zero minimum balance to very low monthly average balance. Waiveoffs and very low monthly service fees are offered to help the new businesses initiate and scaleup.

The length of time required to open a bank account again depends on the availability of all documentation, the process can be very quick between 15 to 45 minutes. The banks do not require a minimum turnover to start a bank account, however, businesses can apply for bank loans only after 36 months of existence and turnover above 20 Lakh. This makes gaining earlystage funding impossible, some banks offer government schemes such as PMMY and start-up India for MSME. Although Indian Banks do not offer loans directly at an early stage of businesses, products like BizCircle, iStartup and Axis Start-up, support them by offering zero balance current account, telebanking support, forex services, advisory, and network building.

Research in the field of entrepreneurship has tremendous scope, this study can be extended to other cities of India at large. Different variables for ease of doing business such as permits, trading across borders, intellectual property protection and foreign funding, etc. should be taken into account to gain a clearer picture.

\section{REFERENCES}

[1] Parker, S. C, The economics of entrepreneurship. Cambridge University Press, 2018.

[2] Van Praag, C. M, Some classic views on entrepreneurship. De economist, 147(3), 1999, 311335.

[3] Makarand Upadhyaya, Abdulsattar Abdulbaqi Alazzawi, Hatem Mohamed EL-Shishini, Deepa Chavan, The Effectiveness of Motivational Strategies on Productivity in Selected Financial Institutions in India. International Journal of Civil Engineering and Technology, 8(9), 2017, pp. $1128-1137$

[4] Drucker, P, Innovation and entrepreneurship. Routledge, 2014.

[5] Forbes India, Entrepreneurship in India - Then and now | Forbes India. [online] Available at: http://www.forbesindia.com/article/spjimr/entrepreneurship-in-india-then-and-now/46701/1, 2019

[6] Lakhwinder Kaur Dhillon and Dr. Upasana Srivastava, the Role of Various Financial Institutions and Regulatory Bodies in Financial Inclusion. Journal of Management, 5(3), 2018, pp. 69-79.

[7] Carton, R. B., Hofer, C. W., \& Meeks, M. D, The entrepreneur and entrepreneurship: operational definitions of their role in society. In Annual International Council for Small Business. Conference, Singapore, 1998.

[8] Priyanka and Dr D.P Jain, "Empirical Study of Development Banks \& Entrepreneurship Promotion", International Journal of Advanced Research in Management (IJARM), Volume 6, Issue 1, January-April (2015), pp. 01-08.

[9] Jones, A. (2019). Entrepreneurship and Financial Institutions Market Analysis. International Journal of Management (IJM), 10(4), 2019, pp 152158. 
[10] Entrepreneur, Sole Proprietorship Definition - Entrepreneur Small Business Encyclopedia. [online] Available at: https://www.entrepreneur.com/encyclopedia/sole-proprietorship [Accessed 7 Nov. 2019].

[11] G. Satheesh Raju and Kafila, Engineering Entrepreneurship from Job Seekers to Job Providers, International Journal of Mechanical Engineering and Technology 8(11), 2017, pp. 735-738.

[12] How to register LLC in India. - Indian Legal Solution, Retrieved from https://indianlegalsolution.com/how-to-register-llc-in-india/, 2019

[13] Partnership Definition - Entrepreneur Small Business Encyclopedia. (2019), Retrieved 7 November 2019, from https://www.entrepreneur.com/encyclopedia/partnership, 2019

[14] What Everyone Should Know About Corporations, Retrieved 7 November 2019, from https://www.investopedia.com/terms/c/corporation.asp, 2019

[15] Why having a PAN card is so important, retrieved 9 November 2019, from https://www.businesstoday.in/moneytoday/tax/permanent-account-number-pan-cardapplication-importance/story/196107.html, 2019. 